\title{
Hepatoprotective and antioxidants activity of ethanolic extract of Cuscutta reflexa roxb
}

\author{
Amrita Richhariya*, Ajay Kumar Singh, Neelima Singh, Sanjeev Kumar Singh \\ Department of Biochemistry, G.R. Medical College and J. A. Group of Hospitals, Gwalior (M.P.), India
}

\begin{abstract}
:
Background and objective: Medicinal plants play a key role in the human health care system. About $80 \%$ of the world populations rely on traditional medicine which is predominantly based on plants material. A large number of plants and purified natural substances have been screened for liver disorders. Liver diseases are mainly caused by toxic chemicals, excess alcohol consumption, infection and auto immune mediated. Most of the hepatotoxic chemicals damage liver cells mainly by lipid peroxidation \& other oxidative damage. In view of above discussion, this study was aimed to evaluate the hepatoprotective and antioxidant activity of ethanolic extract of Cuscutta reflexa in albino rats by inducing liver damage by carbon tetrachloride.

Materials and methods: Liver damage was evaluated by accessing the antioxidants parameters (superoxide dismutase, catalase), lipid peroxidation (Malondialdehyde), serum enzymes (SGOT, SGPT), total protein and bilirubin.

Result: The ethanol extract at on oral doses of $100 \mathrm{mg} / \mathrm{kg}$ exhibited a highly significant $(\mathrm{p}<0.001)$ protective effect by lowering serum levels of lipid peroxidation, serum enzymes and bilirubin. The highly significant $(\mathrm{p}<0.001)$ increase was found in the serum levels of superoxide dismutase, catalase \& total protein. These biochemical observations were supplemented by histopathological examination of liver sections. Furthermore, the ethanol extract showed no significance of toxicity up to a dose level of $100 \mathrm{mg} / \mathrm{kg}$.
\end{abstract}

Conclusion: The results suggested the ethanolic extract of Cuscutta reflexa exhibit significant hepatoprotective properties.

Key words: antioxidants, carbon tetrachloride, cuscutta reflexa, hepatoprotective activity, lipid peroxidation

\section{Introduction}

Liver is the prime organ concerned with various states of metabolic and physiologic homeostasis of the organism. In modern medicine, there is no specific cure for disease such as infectious hepatitis and liver cirrhosis. Free radicals are reactive molecules and are believed to be involved in many physiological processes and human diseases, such as cancer, ageing, cardiovascular disorder, ischemia and inner injury [1]. The elevation of free radicals levels seen during the liver damage is owing to enhanced production of free radicals and decreased potential of cells. A variety of intrinsic antioxidants (superoxide dismutase, catalase and peroxidase) are present in the organism, which protect them from oxidative stress, thereby forming the first line of defense [2]. Various parts of this plant were used in tribal medicine for the disease like fits, melancholy, and insanity. The plant is acrid, bitter taste, astringent to the bowels, aphrodisiac, expectorant, carminative, tonic, purifies the blood and cleanses the body, lessens inflammation, useful in jaundice, pains in the muscles and joints, headache, disease of spleen, vomiting. The stems are especially useful in bilious disorder. Since the plant is parasitic in nature, it absorbs organic and inorganic solutes from host plant, containing number of active phytopharmaceuticals. In folk/tribal medical practice many plants are used to treat many diseases in south India. Most of these medicinal plants are not scientifically validated for their therapeutic efficacy and safety. A scientific study on this plant is likely to provide valuable hepatoprotective drug [3]. Hence, the present study was aimed at evaluating the antioxidant and hepatoprotective activity of ethanolic extract of Cuscutta reflexa against $\mathrm{CCl}_{4}$ induced liver damaged in rats

\section{Materials and methods:}

2.1. Plant material:

The plants were collected from the Campus of Barkatullah University, Bhopal (MP), in the month of January - February, 2007. The plant was identified and authenticated by Department of Pharmacy, Barkatullah University, India. The plants were shade dried at room temperature for 10 days, coarsely powdered with the help of a hand-grinding mill and the powder was used for extraction.

\subsection{Preparation of the extract:}

The powdered plant material $(400 \mathrm{~g})$ of aerial parts of $C$. reflexa was defatted with petroleum ether $\left(60-80^{\circ} \mathrm{C}\right)$ and then extracted separately with 1.5 liter of ethanol (95\%) by Soxhlet apparatus. The extract was dried under reduced pressure, 
which obtained a greenish black sticky residue The dried ethanolic extract $(240 \mathrm{~g})$ was stored in a desiccators till further study. Thus, the plant extract was emulsified by mixing with acacia gum \& castor oil with ratio 1:1:4 ratios.

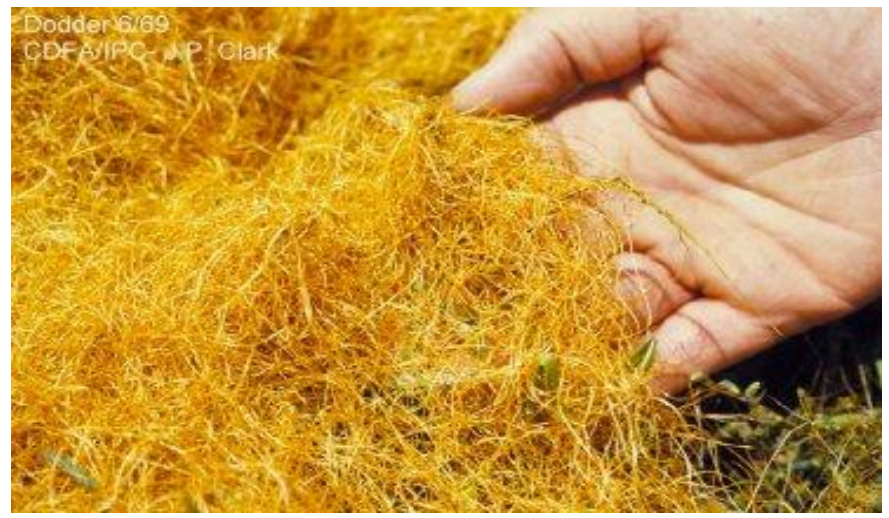

\subsection{Animals:}

Fig 1. Cuscutta reflexa ROXB

Wistar albino rats, 9-12 weeks old with weighed approximately between 110-150gm were purchased from Jahagirabad, Bhopal (MP) and used for the study. They were housed in proper cages and fed with standard diet and water ad libitum. The animals were exposed to alternate cycle of $12 \mathrm{~h}$ of darkness and light each. The experimental protocols were approved by Institutional Animal Ethical Committee

\subsection{Toxicity evaluation in mice:}

Male albino Mice, 9-12 weeks old with average weight of 110-150 gm were used for the study. The ethanol extract was tested for its toxicity in mice. To determine the toxicity, a single oral administration of the ethanol extract of $C$. reflexa in different doses was administrated to different groups of mice (20 mice were used for each group). Mortality and general behavior of the animals were observed periodically for $48 \mathrm{~h}$. The animals were observed continuously for the initial $4 \mathrm{~h}$ followed by $6 \mathrm{~h}, 24 \mathrm{~h}$ and $48 \mathrm{~h}$ after drug administration. The parameters observed were grooming, hyperactivity, sedation, respiratory rate and convulsion.

\subsection{Experimental Design:}

$\mathrm{CCl}_{4}$ solution was prepared in sterile distilled water and was administered by i.p. route for 7 days.

Group I Received normal saline only

Group II Received $\mathrm{CCl}_{4} 0.1 \mathrm{ml} / \mathrm{kg} / \mathrm{day}$ for 14 days

Group III Received $\mathrm{CCl}_{4} 0.1 \mathrm{ml} / \mathrm{kg} / \mathrm{day}+$ Ethanol Extract of Cuscutta reflexa $1 \mathrm{~g} / \mathrm{kg} /$ day for 14 days

\subsection{Biochemical Estimation:}

Rats were sacrificed $1 \mathrm{~h}$ after administration of drug on $14^{\text {th }}$ day. The blood was collected by retro orbital artery bleeding. Blood samples were centrifuged at $3000 \mathrm{rpm}$ to separate the serum and the following biochemical parameters were estimated: ALP (Bessey OA et al.) [4], ALT (Reitzman S, et al. [5], AST (Reitzman S. et al.) [5], total protein (Lowry et.al.) [6] and bilirubin (Mallory HT et al) [7].

\subsection{Histopathological studies:}

The livers were excised quickly and washed with distilled water and removed extra muscle attach to it. After that liver was weighted and minced into small pieces. The liver tissue is homogenized by tissue homogenizer at 3000rpm for $10 \mathrm{~min}$. in phosphate buffer with ratio of 1:10 of liver \& phosphate buffer by weight. After that homogenized tissue was centrifuged at 12000 r.p.m for $45 \mathrm{~min}$. at $4^{\circ} \mathrm{C}$ and supernatant was used for study of Lipid peroxidation (Esterbauver et al method) [8], Catalase (Aebi method) [9], Superoxide Dismutase (Marklund method) [10] and total protein (Lowry et al) [6].

\subsection{Stastical Analysis:}

The mean and standard deviation (SD) values were calculated for each group in case of biochemical parameter (SGOT, SGPT, Alkaline phosphatase and total bilirubin). Data were analyzed by one way ANOWA followed by Dunnett"s test. 


\section{Results:}

The present study was carried out in Department of Pharmacy, Barkatullah University, Bhopal. This study included 60 wistar rats (Male \& Female). Hepatotoxicity is induced by $\mathrm{CCl}_{4}$. the biochemical parameter of different groups is shown in table no. $1 \mathrm{In}$ the $\mathrm{CCl}_{4}$ treated group, the levels of various parameters are ALP (139.5 \pm 4.98), ALT (49.4 \pm 0.3$)$, AST (136.84 \pm 4.24), Total protein $(4.9 \pm 0.139)$ and Total bilirubin $(1.72 \pm 0.06)$. In contrast the group treated with ethanol extract cuscutta reflexa at dose of $(1 \mathrm{~g} / \mathrm{kg})$ once daily for 14 days prevented the hepatotoxicity, thus the level of various parameters are ALP (126.2 \pm 3.06$)$, ALT $(43.28 \pm 2.6)$, AST $(123.44 \pm 3.82)$, Total protein $(5.3 \pm 0.368)$ and Total bilirubin $(1.51 \pm 0.05)$ in a dose related manner. The levels of homogenized lever tissue total protein \& activities of SOD, Catalase \& MDA were significantly decreased in hepatotoxic rats. Oral \& I.P. treatment with ethanol extract of C. reflexa $(1 \mathrm{~g} / \mathrm{kg})$ for 14 days significantly prevented these alteration \& maintained enzyme levels at near normal levels (table no.2).

Table 1: Table showing the status of different biochemical parameters of blood serum of rats.

\begin{tabular}{|l|c|c|c|c|c|}
\hline Group & $\begin{array}{c}\text { ALP } \\
(\mathrm{IU} / \mathrm{L})\end{array}$ & $\begin{array}{c}\text { ALT } \\
(\mathrm{SF} / 100 \mathrm{ml})\end{array}$ & $\begin{array}{c}\text { AST } \\
(\mathrm{SF} / 100 \mathrm{ml})\end{array}$ & $\begin{array}{c}\text { Total Protein } \\
(\mathrm{mg} / \mathrm{ml})\end{array}$ & $\begin{array}{c}\text { Total Bilirubin } \\
(\mathrm{mg} / \mathrm{dl})\end{array}$ \\
\hline Normal Control & & & & & \\
& $105.5 \pm 3.51$ & $30.0 \pm 2.3$ & $90.91 \pm 2.44$ & $5.5 \pm 0.159$ & $0.63 \pm 0.02$ \\
\hline $\mathbf{C C l}_{\mathbf{4}}$ & $139.5 \pm 4.98^{*}$ & $49.4 \pm 0.3^{*}$ & $136.84 \pm 4.24 *$ & $4.9 \pm 0.139$ & $1.72 \pm 0.06^{*}$ \\
\hline $0.1 \mathrm{ml} / \mathrm{kg} /$ day $)$ & $126.2 \pm 3.06^{* *}$ & $43.28 \pm 2.6^{* *}$ & $123.44 \pm 3.82^{* *}$ & $5.3 \pm 0.368$ & $1.51 \pm 0.05^{* *}$ \\
\hline $\mathbf{C C l}_{\mathbf{4}}+$ Plant Extract $(1 \mathrm{~g} / \mathrm{kg} /$ day) & \multicolumn{1}{|l}{} \\
\hline
\end{tabular}

Values expressed as Mean \pm SD

$* * \mathrm{P}<0.001, * \mathrm{P}<0.01$

Table 2: Table showing the status of different biochemical parameters of homogenized liver tissue of rats.

\begin{tabular}{|l|c|c|c|c|}
\hline Group & $\begin{array}{c}\text { SOD } \\
\text { (unit/min/mg } \\
\text { protein) }\end{array}$ & $\begin{array}{c}\text { Catalase } \\
\text { (mole of H2O2 decomposed /min./mg } \\
\text { protein) }\end{array}$ & $\begin{array}{c}\text { MDA } \\
\text { (n mol MDA/100mg } \\
\text { protein) }\end{array}$ & $\begin{array}{c}\text { Total } \\
\text { Protein } \\
(\mathrm{mg} / \mathrm{ml})\end{array}$ \\
\hline Normal Control & $6.32 \pm 0.24$ & $40.26 \pm 2.26$ & $139.2 \pm 24.9$ & $5.74 \pm 0.42$ \\
\hline $\begin{array}{l}\mathbf{C C l}_{\mathbf{4}} \\
(0.1 \mathrm{ml} / \mathrm{kg} / \text { day) }\end{array}$ & $4.20 \pm 0.15^{* *}$ & $22.93 \pm 1.75^{*}$ & $342.9 \pm 47.8^{* * * *}$ & $12.86 \pm 5.02$ \\
\hline $\begin{array}{l}\mathbf{C C l}+\mathbf{P l a n t} \text { Extract } \\
(1 \mathrm{~g} / \mathrm{kg} / \mathrm{day})\end{array}$ & $6.08 \pm 0.22^{* *}$ & $38.57 \pm 1.83^{*}$ & $162.0 \pm 27.3^{* * *}$ & $6.87 \pm 1.41$ \\
\hline
\end{tabular}

Values expressed as Mean \pm SD

$* * \mathrm{P}<0.001, * \mathrm{P}<0.01$ 


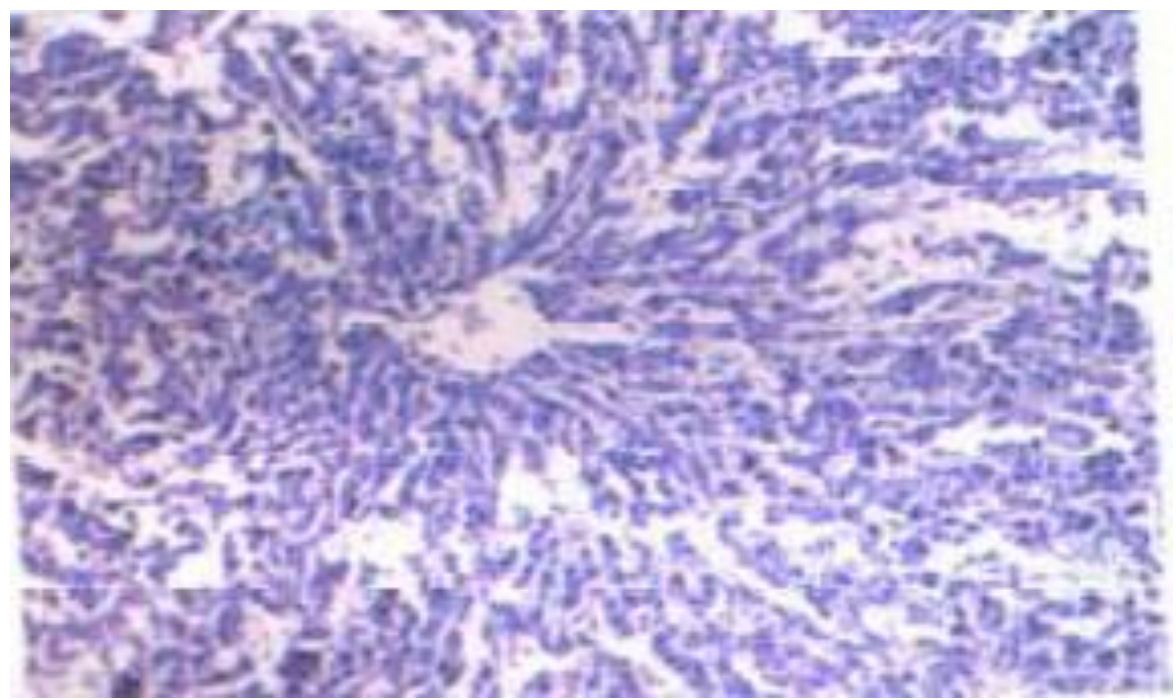

Fig.1: The liver cells of normal rat exhibit normal architecture of hepatocytes there is no sign of necrosis or degeneration. The lobes of the liver are made up of many functional units called lobules. A lobule consists of specialized epithelial cells called Hepatocytes arranged in irregular branching interconnected plates around the central vein.

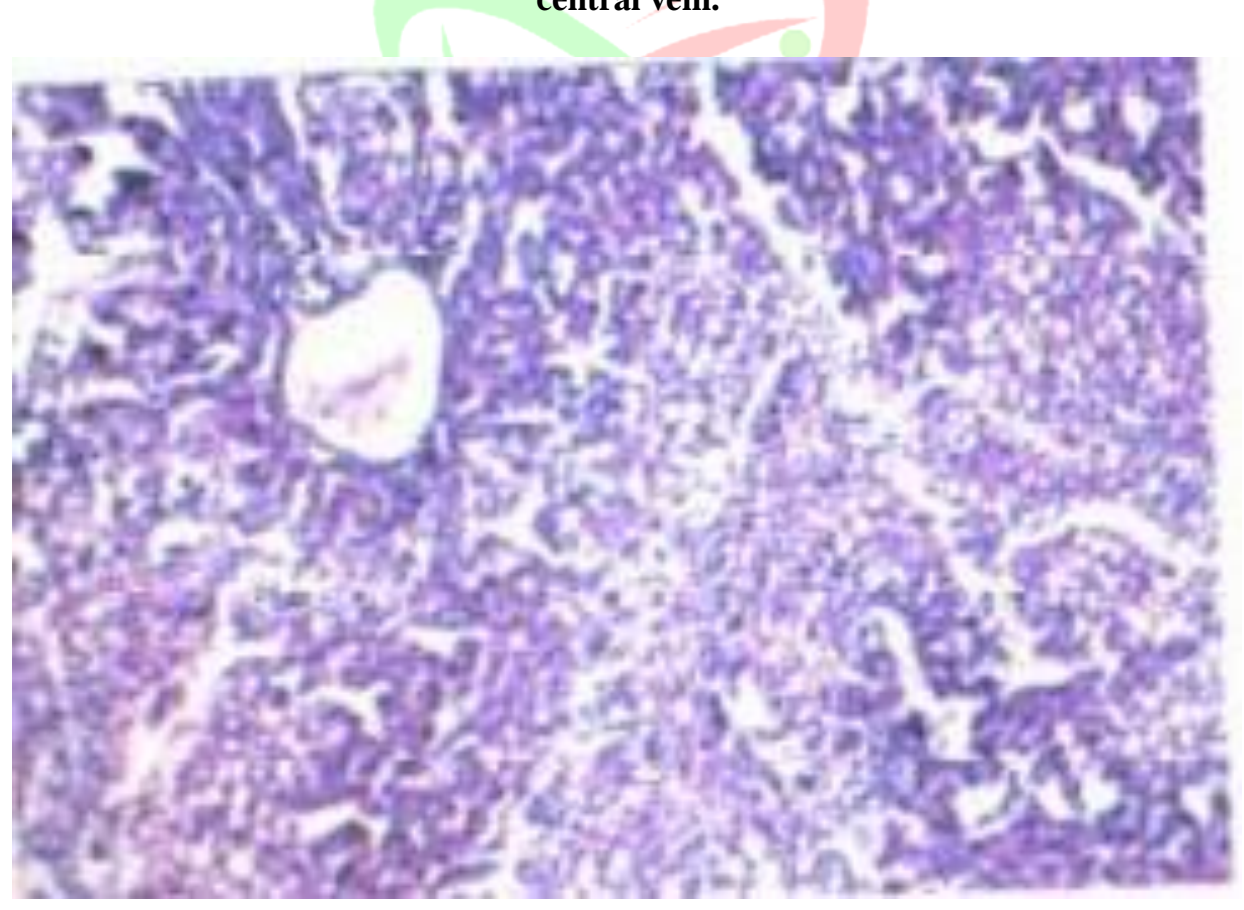

Fig.2: The $\mathrm{CCl}_{4}$ treated rats liver shows cellular degeneration more around the central vein, fatty acid degeneration and hepatocellular necrosis. The normal architecture of liver is completely damaged. 


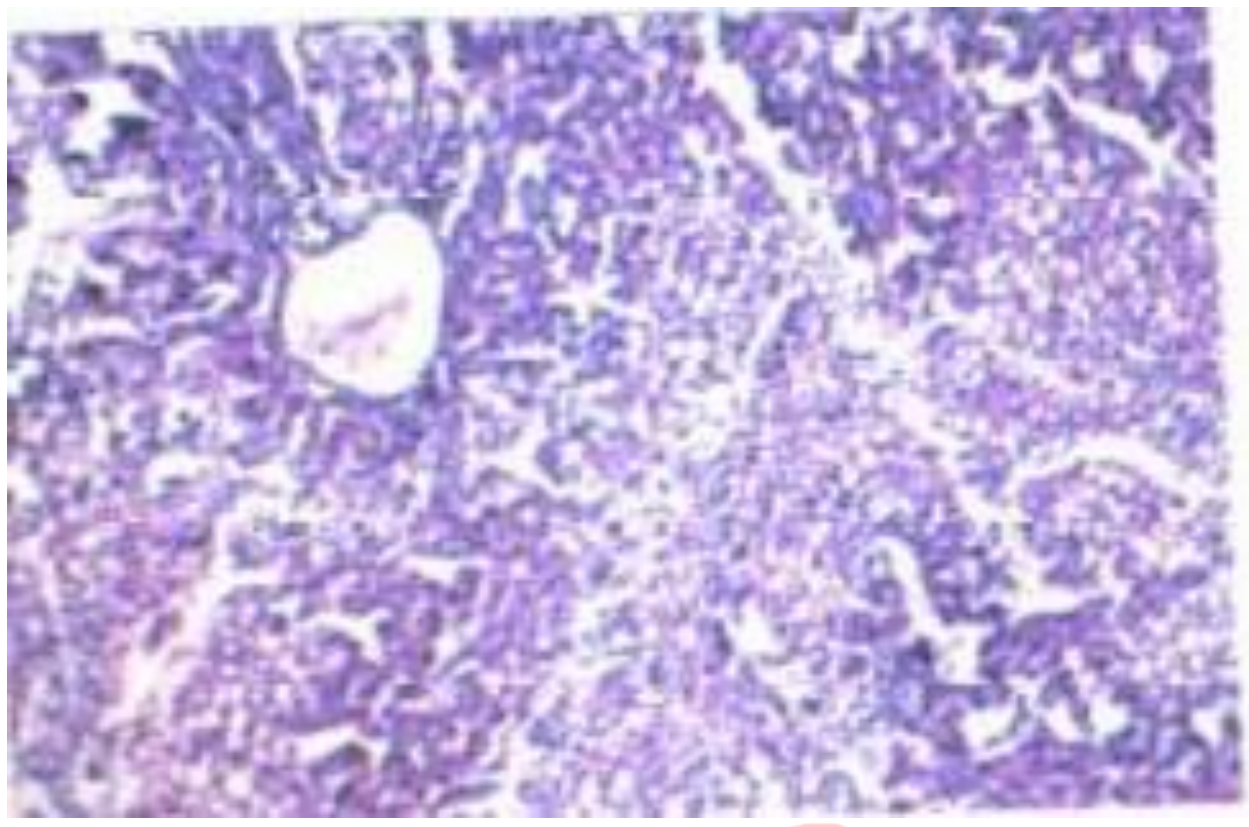

Fig.3: Initiation of regeneration of hepatic cells was observed in case of standard drug treatment. Normal cells structure was observed which indicates very significant regeneration of hepatic cells. Hepatic cells are mostly normal so it shows that Cuscutta reflexa shows the hepatoprotective activity

\section{Discussion:}

The liver can be injured by many chemicals \& drugs. In the present study $\mathrm{CCl}_{4}$ was selected as a hepatotoxicant to induce liver damage [11]. The chronic liver disease occurs due to accumulation of lipids \& proteins in hepatocytes [12] with an impaired protein secretion by hepatocytes [13]. During hepatic damage cellular enzymes ALP, ALT \& AST present in the liver cells leak into the serum, resulting in increased concentration [14]. $\mathrm{CCl}_{4}$ administration for 14 days significantly increases all these serum enzymes and bilirubin while total protein is decreased. The ethanolic extract of Cuscutta reflexa presented animals had significantly reduced ALP, AST, ALT \& total bilirubin whereas, total protein concentration is increased, and indicating their hepatoprotective effect against $\mathrm{CCl}_{4}$ induced liver damage, which is consistent with the report by Balakrishnan $\mathrm{BR}$ et al [3]. $\mathrm{CCl}_{4}$ induced liver damage by cellular degeneration more around the central vein, fatty acid degeneration \& hepatocellular necrosis. Histopathological studies of $\mathrm{CCl}_{4}$ induced liver tissue of rat shows decreased concentration of antioxidants enzymes SOD, Catalase \& Peroxidase. The ethanolic extract of Cuscutta reflexa presented animals shows increased activity of all these antioxidants enzymes.

\section{Conclusion:}

Ethanolic extract of Cuscutta reflexa improved liver function by decreasing the serum ALT, AST, ALP levels in hepatotoxic rats. Although there will be an increasing AST \& ALT in heart \& liver diseases, the increase of AST is more in heart diseases and ALT is higher in liver diseases . Total bilirubin of by product of the breakdown of Red blood cells in the liver, is a good indicator of liver function, high levels cause jaundice \& indicative of damage to the liver \& bile duct. Ethanol extract of Cuscutta reflexa reduce all these serum enzymes as will as total bilirubin \& improve activity of antioxidant enzymes levels, indicating its protective effect of liver \& improvement of its functional efficiency.

\section{References:}

1. J.M. Mates, C.P. Gomez, et al, Antioxidant enzymes and human diseases, Clinical Biochemistry, 32, 1999, 595603.

2. R. Sondhir and K.D. Gill, Hepatoprotective effect of Liv-52 on ethanol induced liver damage in rats, Indian journal of experimental bilogy, 37, 1999, 762-766.

3. B.R. Balakrishnan, B. Sangameswaran and V.H. Bhaskar, Effect of methanol extract of cuscutta reflexa aerial parts on hepatotoxicity induced by antitubercular drugs in rats. International Journal of Applied Research in Natural Products, 3(1), 2010, 18-22. 
4. O.A. Bessey, D.M. Lowery and M.J. Brock, A method for determination of alkaline phosphatase with five cubic millimeter of serum, J Biol Chem, 164, 1964, 321-329.

5. S. Reitzman and S. Frankel, A calorimetric method for determination of serum glutamic oxalloacetic acid, glutamic pyruvic transaminase. Amer J Clin Path, 28, 1957, 56-63.

6. O.H. Lowry, N.J. Rosebrough, A. L. Farr and R.J. Randoll , Protein measurement with the Folin- Phenol reagents, J Biol Chem, 193, 1951, 265-275.

7. H.T. Mallory and E.A. Evelyn, The determination of bilirubin with phosphoelectric calorimeter, $J$ Biol Chem, 119, 1937, 481-485.

8. H. Esterbauer, K.H. Cheeseman, M.U. Dianzi, G. Poli, and T.F. Slater, Separation and characterization of the aldehydic products of lipid peroxidation stimulated by ADP-Fe ${ }^{2+}$ in rat liver microsomes, Biochem J, 208, 1982, 129-140.

9. H. Aebi, Catalase in vitro, Methods in Enzymology, 105, 1984, 121-126.

10. S. Marklund and G. Marklund, Involvement of superoxide anion radical in the antioxidation of pyrogallol and a convenient assay for superoxide dismutase, Eur J Biochem, 47, 1974, 469-474.

11. M.A. Leo and M. Arai, Hepatotoxicity of vitamin A and ethanol in rat, Gastroenterology, 82, 1982, $194-205$.

12. L. Ashakumary and P.L. Vijayammal, Additive effect of alcohol \& nicotine on lipid metabolism in rats, Indian J Exp Biol, 31, 1993, 270-274.

13. H. Vilstrup and N. Tygstrup, Glucoregulation in acute liver failure. Eur J clin Invest, 16, 1985, $193-197$.

14. A.C. Deb, Fundamentals of Biochemistry, $7^{\text {th }}$ ed, New Central Book Agency: Kolkata, 1998. 